\title{
Phenotypic variation in Pentaclethra macrophylla Benth (Fabaceae) from the humid lowlands of Cameroon
}

\author{
Alain Tsobeng, Zac Tchoundjeu, Ann Degrande, Ebenezer Asaah, \\ Takoutsing Bertin (1), Patrick Van Damme $(2,3)$ \\ (I) World Agroforestry Centre, Yaoundé, Cameroon \\ (2) Laboratory of Tropical and Subtropical Agriculture and Ethnobotany \\ Ghent University, Belgium \\ (3) Department of Crop Sciences and Agroforestry, Prague University \\ Czech Republic
}

\begin{abstract}
Pentaclethra macrophylla Benth (Fabaceae) has emerged as one of the top underutilized agroforestry species with considerable economic and nutritional value in West and Central Africa where the species is endemic and exploited by farmers. However, the species suffers from a level of exploitation that is unsustainable. This dramatically decreases the natural resource base. Key information such as tree variation is needed to develop an efficient strategy for its domestication. This study therefore assesses the species phenotypic variation in two populations in the forest zone of Cameroon. Overall, 49 trees (I9 in Lomie and 30 in Djoum) were sampled. Tree characteristics (diameter at breast height (DBH), height, crown diameter), pod (number of seeds per pod), seed (width, length, thickness, weight) and kernel traits (weight) were recorded. All these parameters were subjected to a combination of multivariate, PCA and cluster analyses. Results revealed four clusters of P. macrophylla trees with cluster IV considered as the best because it contains four elite trees (LOM/PM/og, $\mathrm{LOM} / \mathrm{PM} / \mathrm{I} 3, \mathrm{LOM} / \mathrm{PM} / \mathrm{I5}$ and LOM/PM/I6) with desirable tree characteristics. Clusters were further considered as different groups of trees, and seeds and kernel traits variation assessed using ANOVA analysis. Significant differences in mean kernel weight occured between groups. Cluster IV presented the highest mean kernel weight ( $19.25 \pm 0.16 \mathrm{~g}$ ), while cluster III had the lowest (I3.28 $\pm 0.57 \mathrm{~g})$. Within cluster IV, the highest kernel weight $(25.83 \pm 5.62 \mathrm{~g})$ was found in tree number LOM/PM/og. Kernel weight was found to be positive and strongly correlated $(r=0.95)$ with seed weight. We can conclude that there is phenotypic variation between the trees of P. macrophylla in terms of DBH, height, crown diameter, number of seeds, seed width, seed length, seed thickness, seed and kernel weight. Results obtained in this study could serve as a useful guide for the selection of targeted P. macrophylla trees either for domestication or for conservation purposes.
\end{abstract}

Key words: Pentaclethra macrophylla, Ideotype, kernel weight, tree selection, tree variation 


\section{Introduction}

Pentaclethra macrophylla Benth (Fabaceae), commonly called ebaye in Cameroon, is an important fruit tree species of the humid forest zone of West and Central Africa. It has hermaphrodite flowers, producing long-suspended, woody and dehiscent pods. When mature, the pod liberates oval or round flat seeds. Mature P. macrophylla trees can reach 30 $\mathrm{m}$ in height, with a tree trunk diameter at breast height of $80 \mathrm{~cm}$ (Eyog Matig et al., 2006). The species is found in the tropical area from Senegal to the Democratic Republic of Congo passing through south eastern Sudan as well as via Sao Tomé and Principe Islands (Ladipo and Boland, I995; Vivien and Faure, I996; Oboh, 2007).

In recent years, P. macrophylla has drawn the interest of farmers in these production areas because its products (leaves, kernels and bark) have important nutritional and medicinal value (World Agroforestry Centre, 2009). Oboh (2007) reported that in the African humid forest zone, kernels are boiled or roasted and then consumed. In the southern part of Nigeria, seeds are fermented to obtain a condiment called Ugba that has a taste close to that of meat. Kernels are also a source of food oil. This explains why the species is also called "oil bean tree" (Gill, I992). The seed is composed of $30-36 \%$ oil, suitable for soap and candle making (Ehiagbonare and Onyibe, 2008). Mature fruits of P. macrophylla are used for the treatment of human and animal diseases (Oboh, 2007). Extracts of leaves, barks, seeds, and seed pulp have anti-inflammatory and analgesic properties, and are used to treat gonorrhea and convulsions. The roots are also used as a laxative and contribute in the treatment of dysentery. In Cameroon, a decoction made from the bark is used to interrupt pregnancy, whereas the bark is used to send away evil spirits (Koné et al., 2008).

The establishment of a market information system for non-timber forest products has greatly promoted the development of the value chain for P. macrophylla (Ngueko, 2008). Recently, a new market for the species kernels has been developed in Nigeria with about 15 million potential consumers (Mbong, 2009).

P. macrophylla is a victim of unsustainable exploitation characterized by the burning and destruction of seedlings during agricultural field preparation, predation of seeds by wild animals, and over-exploitation of bark by farmers and traditional medical practitioners. If action is not taken to protect the species, serious erosion of the stock will occur with negative consequences for product availability. To address this issue, Mandeng (2009) in collaboration with farmers, identified domestication as a vital alternative, compared to wild harvesting. Domesticating this species will not only improve household revenue (through the development of a profitable marketing strategy), but will enhance food security (by providing an alternative, high-quality food source in sufficient quantities), and also could help reduce deforestation and environmental degradation (Leakey, 200I).

Tree domestication refers to how people select, manage and propagate trees ( $\mathrm{Si}$ mons and Leakey, 2004). Some defining factors controlling vegetative or sexual propagation in view of production of improved planting material of this species were already investigated (Ehiagbonare and Onyibe, 2008; Tsobeng et al., 2013). Initial research showed 
that genetic variation in the species should be better understood, so that farmers can properly identify appropriate mother trees as sources of planting and eventually breeding material. Forest tree species generally have a large phenotypic variation. As a consequence, successful domestication will be based on the characterization and identification of superior individuals within this diverse germplasm. Subsequently, these specimens will be the source of germplasm that can then be conserved in a gene bank as stockplant or mother block from where farmers or other stakeholders can easily get supplies. Leakey and Page (2006) highlighted the importance of an "ideotype" development in cultivar improvement and tree genetic resource conservation, and supported a participatory approach involving researchers, farmers and other beneficiaries. The term "ideotype" was conceived by Donald (I968) as an aid to assist breeding programs in developing putative cultivars of interest to specific consumers and industries. Characterization of phenotypic variation is an important starting point in "ideotype" development since it orients researchers to populations and trees where adequate characteristics can be found (Leakey and Page, 2006).

Several agroforestry trees species in the humid tropics of West Africa have already been characterized: Irvingia gabonensis (Atangana et al., 200I; Leakey and Page, 2006), Dacryodes edulis (Waruhui et al., 2004), Ricinodendron heudelotii (Ngo-Mpeck et al., 2003), Allanblackia floribunda (Atangana, 2010); in the semi-arid zones of West Africa, Adansonia digitata (Assogbadjo et al., 2005), Phoenix dactilifera (Bodian et al., 2010), and Balanites aegyptiaca (Abasse et al., 20II) have been studied. However, nothing has so far been done for P. macrophylla. We therefore present here our research on mapping intraspecific variation in the species with a view to increasing its domestication potential. More specifically, we assessed variation (I) between populations and (2) within populations for the following traits: diameter at breast height (DBH), tree height, crown diameter, number of seeds per pod, seed traits (width, length, thickness and weight) and kernel weight.

\section{Material and method}

Study sites

The study was conducted in two localities in Cameroon, i.e. Lomie ( $\left.3^{\circ} \mathrm{IO} \mathrm{O}^{\prime} \mathrm{N}, \mathrm{I} 3^{\circ} 37^{\prime} \mathrm{E}\right)$ and Djoum $\left(2^{\circ} 4 \mathrm{O}^{\prime} \mathrm{N}, 12^{\circ} 4 \mathrm{O}^{\prime} \mathrm{E}\right)$. These areas are situated at $6 \mathrm{I} 2 \mathrm{~m}$ and $599 \mathrm{~m}$ above sea level, respectively. Both are located in the humid lowland forest zone with a bimodal rainfall pattern characterized by 4 distinct seasons, 2 dry seasons (December to February and July) and two rainy seasons (March to June, August to November). Djoum is located in the South region, while Lomie is situated in the East region of Cameroon (Figure I). As described by Ambassa-Kiki (2000), these sites are characterized by a humid forest vegetation with an average temperature and yearly rainfall of $250 \mathrm{C}$ and I $800 \mathrm{~mm}$, respectively. 


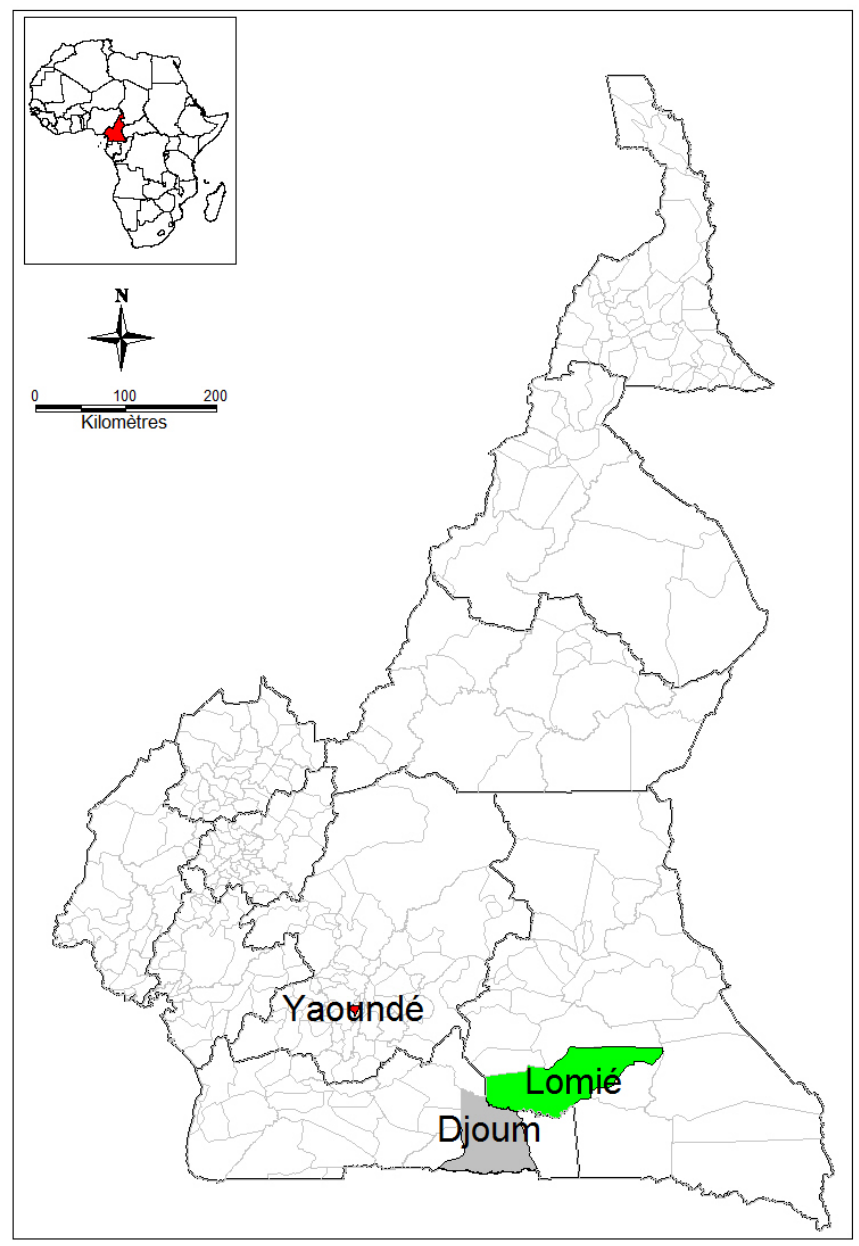

Figure 1: Study sites

Tree sampling method and seeds collection

Djoum and Lomie were chosen because they are the main kernel collection areas of ebaye seeds. In each locality, trees were chosen using a snowball approach. Grassroot organizations guided the data collection teams to a farmer who had the species on his farm. After sampling, the farmer led the team to the next farmer who had trees, and so one. During sampling, care was taken to avoid relatedness bias by choosing trees at least Ioo $\mathrm{m}$ apart using a Global Positioning System (GPS) device. Each tree was labeled and information concerning its characteristics, owner's name locality and GPS coordinates were recorded.

P. macrophylla seeds are usually gathered on the ground, but the seeds may come from different trees. To avoid collection of seeds from unidentified individuals, mature pods were harvested on each tree sampled. Seeds were harvested from four opposite positions on the tree crown as described by Waruhiu et al. (2004). 


\section{Data collection}

A total of 49 trees (I9 in Lomie and 30 in Djoum) were sampled. Thirty pods and 30 seeds per pod were collected randomly from each tree. Traits considered in this study were tree development traits (diameter at breast height (DBH), height and crown diameter), pod (number of seeds), seed (width, length, thickness and weight) and kernel traits (weight). DBH was measured using a forest tape (o.I cm of precision). Tree height was assessed using a SUUNTO clinometer. Due to the irregular form of the crown, its diameter was estimated by taken the average after measuring two axis' lengths at 90 degrees to each other as suggested by Mac Dicken et al. (I99I). The following formula was applied:

$$
\mathrm{CrD}=(\mathrm{d} \mathrm{I}+\mathrm{d} 2) / 2
$$

Where:

$\mathrm{CrD}=$ Crown diameter

$\mathrm{d} \mathrm{I}=$ diameter of the maximum axis of the projected crown

$\mathrm{d} 2=$ diameter of the second axis, making 900 of angle with $\mathrm{d}_{\mathrm{I}}$

Fruit and seed traits were assessed at the ICRAF laboratory at Nkolbisson, Yaoundé, Cameroon. The number of seeds per pod was evaluated by extracting them from fruit pulp and counting. Width, length and thickness (Figure 2) of the seeds were measured using calipers, graduated at o.I mm. Seed and kernel weights were estimated using high precision kitchen scales (o.or g).

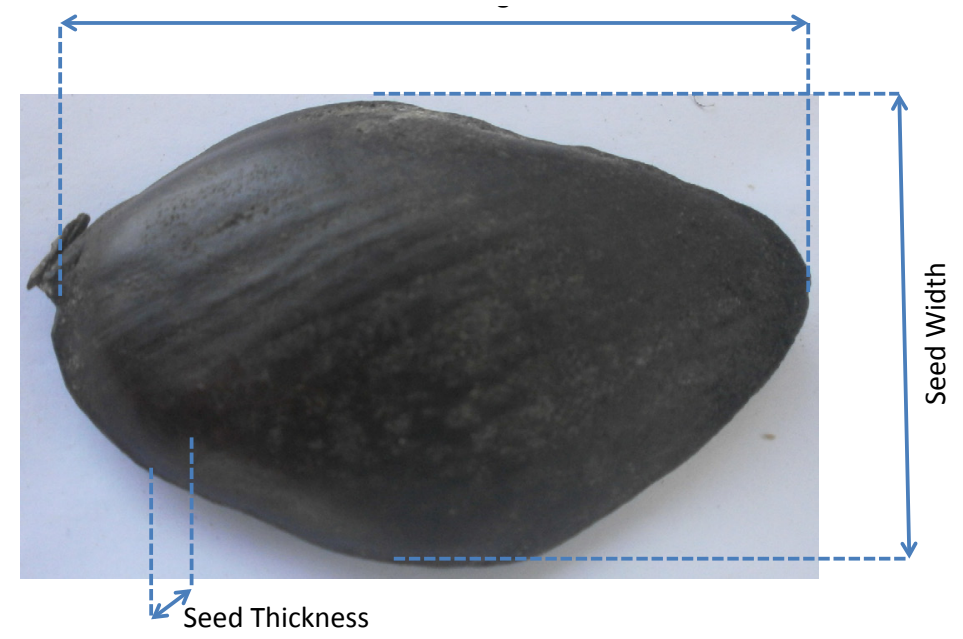

Figure 2: Seed with measured characteristics

\section{Data analysis}

The collected data were subjected to a combination of PCA and cluster analyses using SPSS V.I7 software. Component matrix and rotated component matrix (Tables I and II) were used to identify the number of PCA graph axes and the traits with highest ef- 
fect on variance. Hierarchical cluster analysis was carried out to group individuals. PCA graphs were used to group individuals based on their respective tree traits. The statistical difference between populations and clusters in terms of tree height, tree DBH, crown diameter, number of seeds per pod, seed width, seed length, seed thickness, seed and kernel weight was assessed by conducting analysis of variance (after testing the normality) in order to show significant differences between means ( $\mathrm{P}=0.05)$ (Waruhiu et al., 2004). Pearson $r$ correlations and linear regression model were used to investigate relationships among pod and kernel variables (Abasse et al., 20II). Following Leakey et al. (2000), a web diagram of the phenotypic variation of all seed and kernel traits was used to define elite trees.

\begin{tabular}{lrrr}
\hline Component & \multicolumn{3}{c}{ Initial Eigenvalues } \\
\hline & Total & \% of Variance & Cumulative \% \\
\hline I & $2 . \mathrm{I}$ & $42 . \mathrm{I}$ & $42 . \mathrm{I}$ \\
\hline 2 & I.I & $2 \mathrm{I} .3$ & 63.4 \\
\hline 3 & 0.8 & I6.I & 79.5 \\
\hline 4 & 0.6 & II.7 & 91.2 \\
\hline 5 & 0.4 & 8.8 & I00.0 \\
\hline
\end{tabular}

Table 1: Total variance explained

\begin{tabular}{lcr}
\hline Tree and pod parameters & Component & \\
\hline & I & 2 \\
\hline Tree DBH $(\mathrm{cm})$ & 0.8 & $-0 . \mathrm{I}$ \\
\hline Crown diameter (m) & 0.8 & 0.3 \\
\hline Tree height (m) & 0.7 & 0.3 \\
\hline Number of seeds per pod & 0.2 & 0.8 \\
\hline
\end{tabular}

Table 2: Rotated component matrix

\section{Results}

Variation between populations

We found a significant difference $(\mathrm{P}=0.023)$ in terms of number of seeds per pod between Djoum and Lomie. The difference between populations was insignificant $(\mathrm{P}=$ $0.68,0.45$ and 0.75 respectively) for tree $\mathrm{DBH}$, crown diameter and tree height. The highest number of seeds per pod was observed in Lomie (7.04 \pm I.I8) with the lowest number for Djoum (6.03 \pm 0.14$)$. Seed and kernel parameters significantly differentiated populations, with probabilities of <0.00I, <0.00I, 0.017, <0.00I and <0.00I for seed diameter, seed depth, seed length, seed weight and kernel weight respectively. Both for seed and kernel parameters, Lomie's population performed significantly better than that of Djoum (Figure 3). Lomie had the greatest proportion of tree in the positive parts of the 
two axes of the graph (Figure 4), indicating its superiority in tree traits and pods parameters. PCA for each population revealed the best performing trees as LOM/PM/9, LOM/ $\mathrm{PM} / \mathrm{I} 3, \mathrm{LOM} / \mathrm{PM} / \mathrm{I} 5$ and LOM/PM/I6 in Lomie, and DJ/PM/2I, DJ/PM/24 and DJ/PM/47 in Djoum (Figure 4).

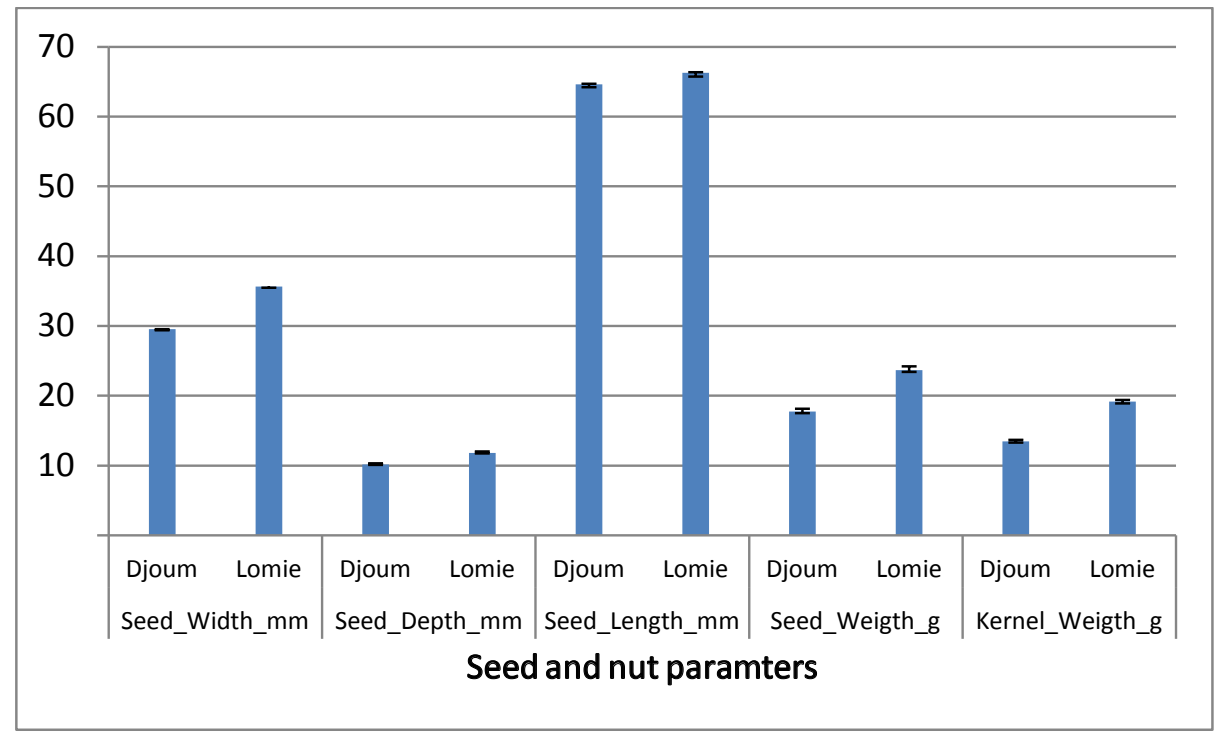

Figure 3: Variation in seed and kernel parameters between P. macrophykka populations

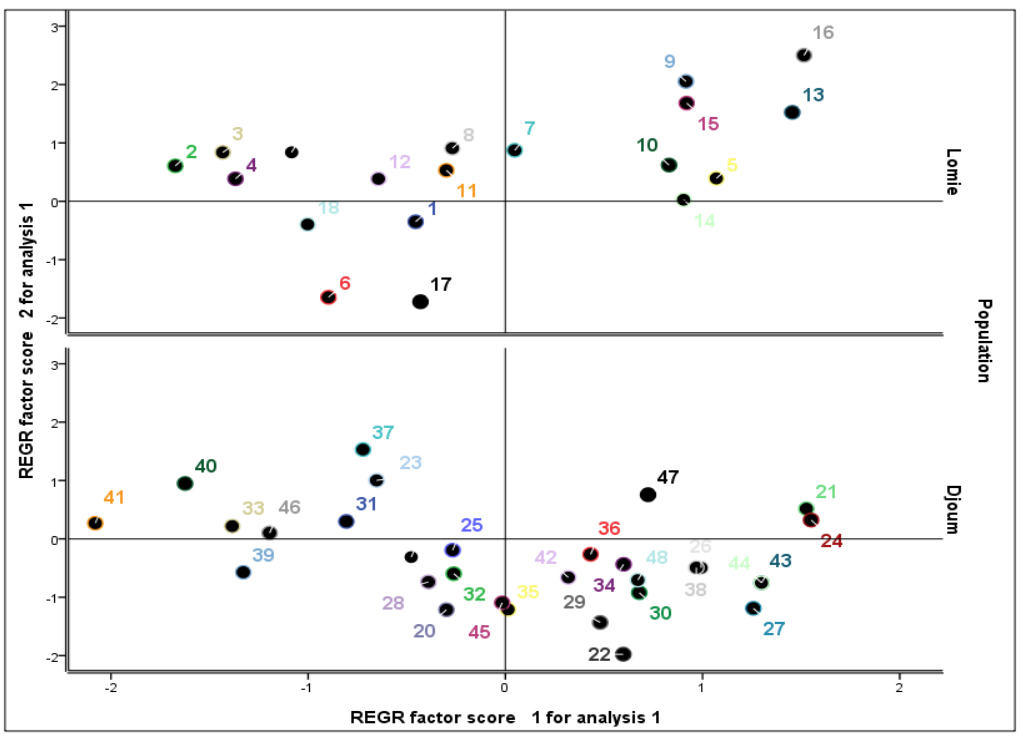

Figure 4: PCA per P. macrophylla population 


\section{Variation within population}

Tree and pod characteristics

Tables I and 2 show two PCA axes with the highest variance for tree $\mathrm{DBH}$, crown diameter, tree height (Component I) and number of seeds per pod (Component 2). A general analysis of trees independent of population revealed four clusters (Figure 5 and 6). From the PCA and a clustering graph (Figures 5 and 6), it was observed that cluster I is composed of trees with low DBH, low crown diameter, low tree height and low number of seeds per pod, while cluster II is made up of trees with low tree $\mathrm{DBH}$, low crown diameter, low tree height and high number of seeds per pod. Cluster III includes trees with high tree DBH, high crown diameter, high tree height and low number of seeds per pod, while cluster IV trees were grouped based on trees that showed the highest values for four parameters (height, DBH, crown diameter, number of seeds per pod). Figures 4 and 5 show cluster IV composed of trees that are superior in terms of the studied traits from the Lomie population. These trees are LOM/PM/9, LOM/PM/I3, LOM/PM/I5 and LOM/ $\mathrm{PM} / \mathrm{I} 6$. The differences are highly significant $(\mathrm{P}<\mathrm{0.00I}$ ) between clusters for all studied tree and pod parameters. Cluster IV had the highest number of seeds per pod, highest crown diameter and highest tree height. Meanwhile, cluster III showed the best results in terms of tree DBH (Table 3).

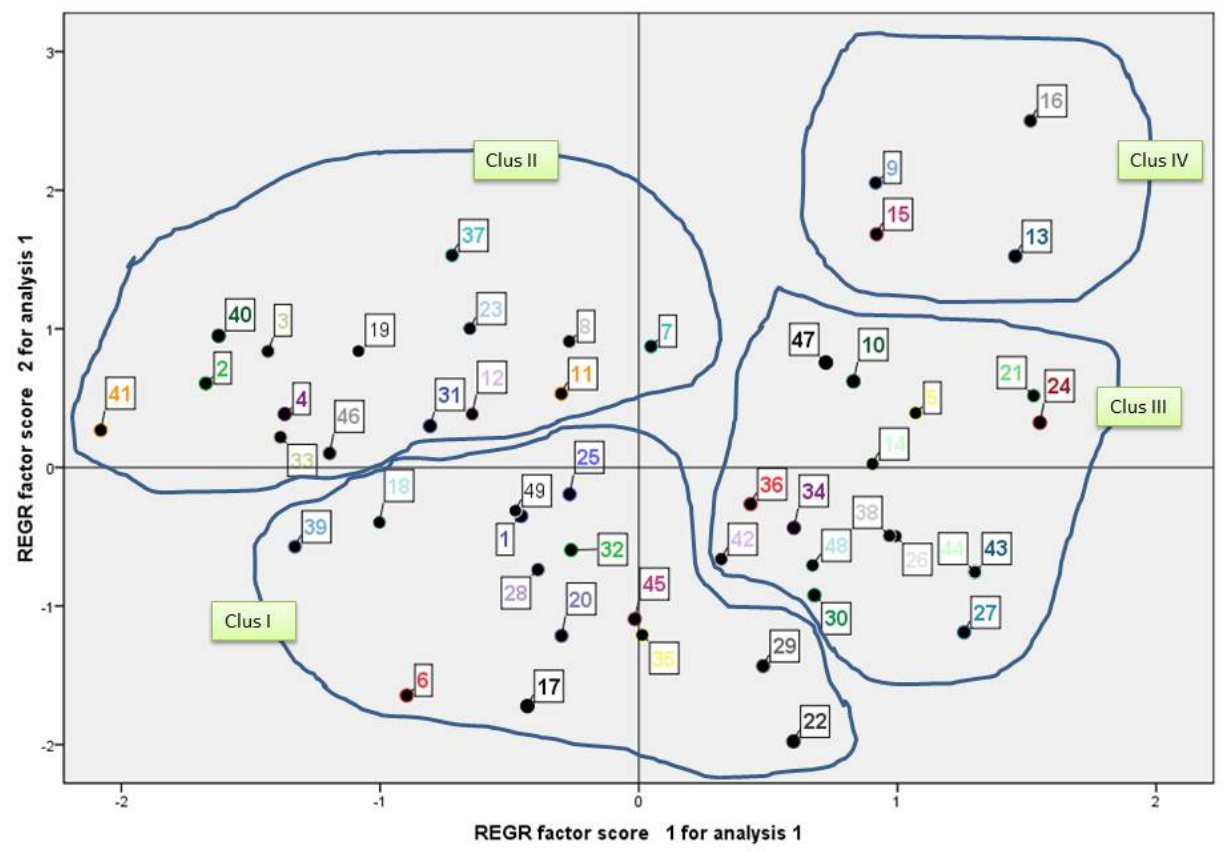

Figure 5: General PCA for the two P. macrophylla populations 


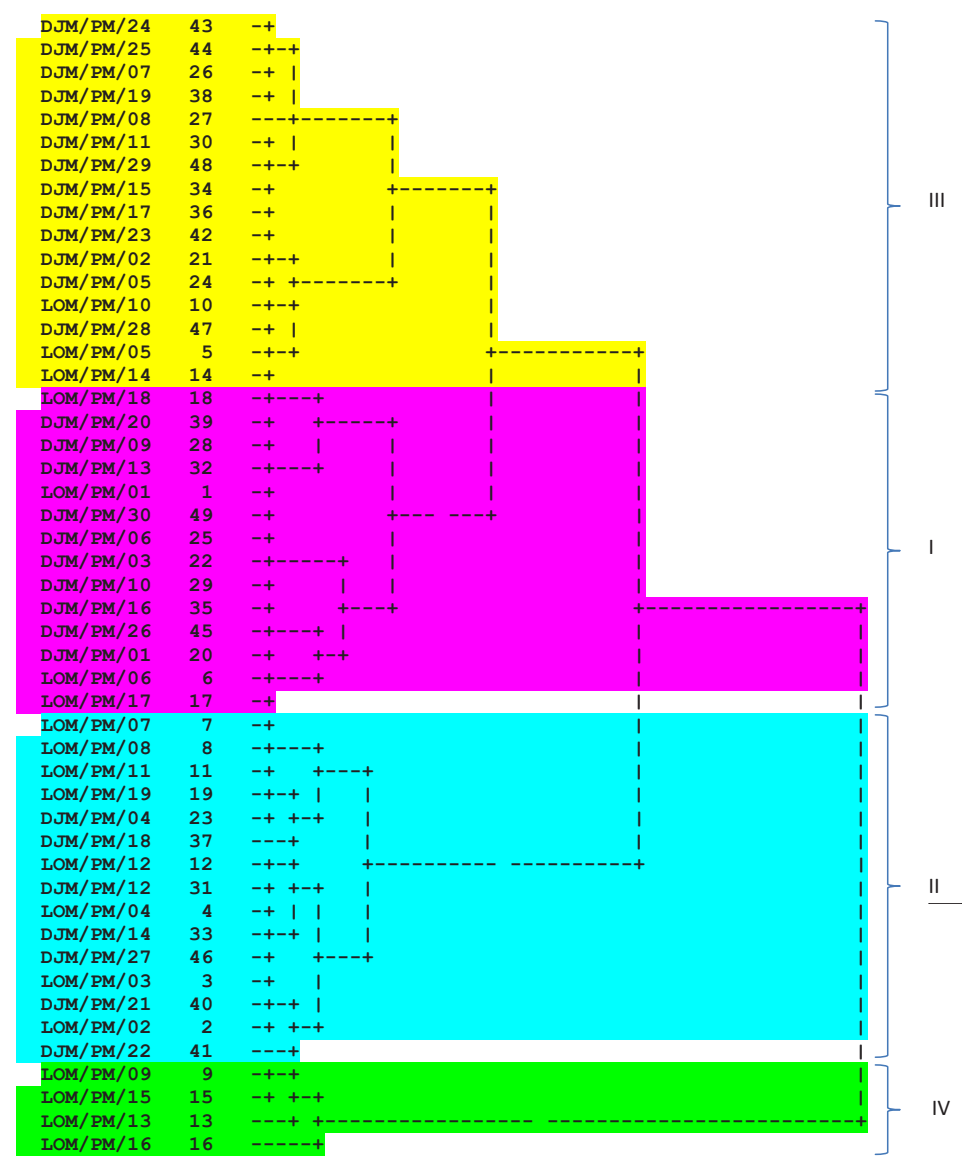

Figure 6: Hierarchical cluster analysis result 


\begin{tabular}{|c|c|c|}
\hline Dependent Variable & $\begin{array}{l}\text { Average Linkage } \\
\text { (Between Groups) }\end{array}$ & Mean \\
\hline \multirow[t]{4}{*}{ Tree height $(\mathrm{m})$} & CLUS I & $30.4 \mathrm{I} \pm \mathrm{I} .57 \quad \mathrm{a}$ \\
\hline & CLUS 2 & $3 \mathrm{I} .53 \pm \mathrm{I} .52 \mathrm{a}$ \\
\hline & CLUS $_{3}$ & $36.66 \pm \mathrm{I} .45 \quad b$ \\
\hline & CLUS $_{4}$ & $46.25 \pm 2.94 \quad c$ \\
\hline \multirow[t]{4}{*}{ Tree DBH $(\mathrm{cm})$} & CLUS I & $68.54 \pm 5.34 \quad a$ \\
\hline & CLUS 2 & $5 \mathrm{I} .48 \pm 5 . \mathrm{I} 6 \mathrm{~b}$ \\
\hline & CLUS $_{3}$ & $105.68 \pm 4.99 \quad c$ \\
\hline & CLUS $_{4}$ & $84.43 \pm 9.99 \mathrm{~d}$ \\
\hline \multirow[t]{4}{*}{ Crown diameter $(\mathrm{m})$} & CLUS I & $17.66 \pm 0.97 \quad \mathrm{a}$ \\
\hline & CLUS 2 & $\mathrm{I} 5.33 \pm 0.94 \mathrm{~b}$ \\
\hline & CLUS $_{3}$ & $23.29 \pm 0.91 \quad c$ \\
\hline & CLUS $_{4}$ & $29.50 \pm \mathrm{I} .8 \mathrm{I} \quad \mathrm{d}$ \\
\hline \multirow[t]{4}{*}{ Number of seeds per fruit } & CLUS I & $5.50 \pm 0.17 \quad a$ \\
\hline & CLUS 2 & $6.53 \pm 0.16 \quad b$ \\
\hline & CLUS $_{3}$ & $6.31 \pm 0.16 \quad b$ \\
\hline & CLUS $_{4}$ & $7.50 \pm 0.31 \quad c$ \\
\hline
\end{tabular}

Table 3: Mean values of tree and pod parameters in four clusters (clusters with the same letters for the same variable are not significantly different)

Seed and kernel characteristics

Selected seed traits (width, length, thickness, weight) and kernel weight were significantly different between clusters $(\mathrm{P}<\mathrm{o.00I}$ ). Cluster IV was the best group of trees for the different seed traits, while the order of the other clusters depended on seed traits (Figure 7). 


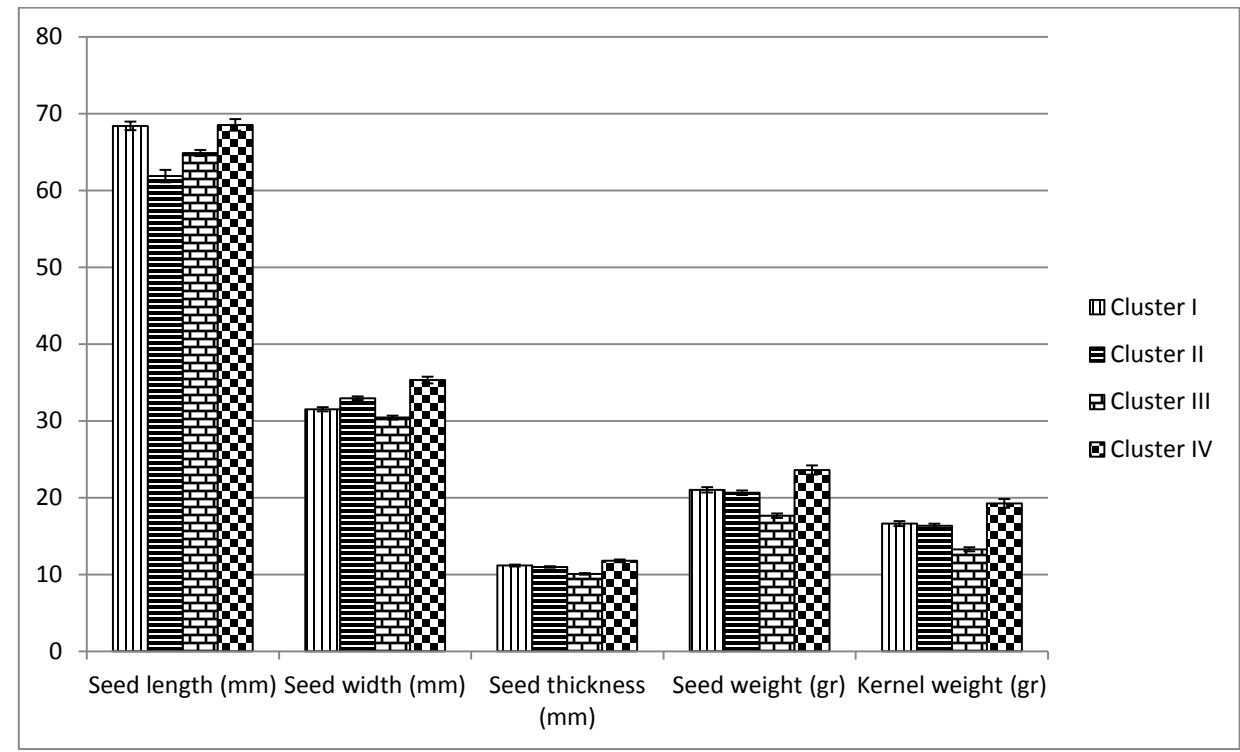

Figure 7: Means of P. macrophylla seed parameters between clusters

From the web diagram of cluster IV (Figure 8), it can be seen that tree LOM/PM/o9 had the greatest seed depth, seed weight and kernel weight. Seed width was highest for tree LOM/PM/I6, while seed length was greatest for tree LOM/PM/I3.

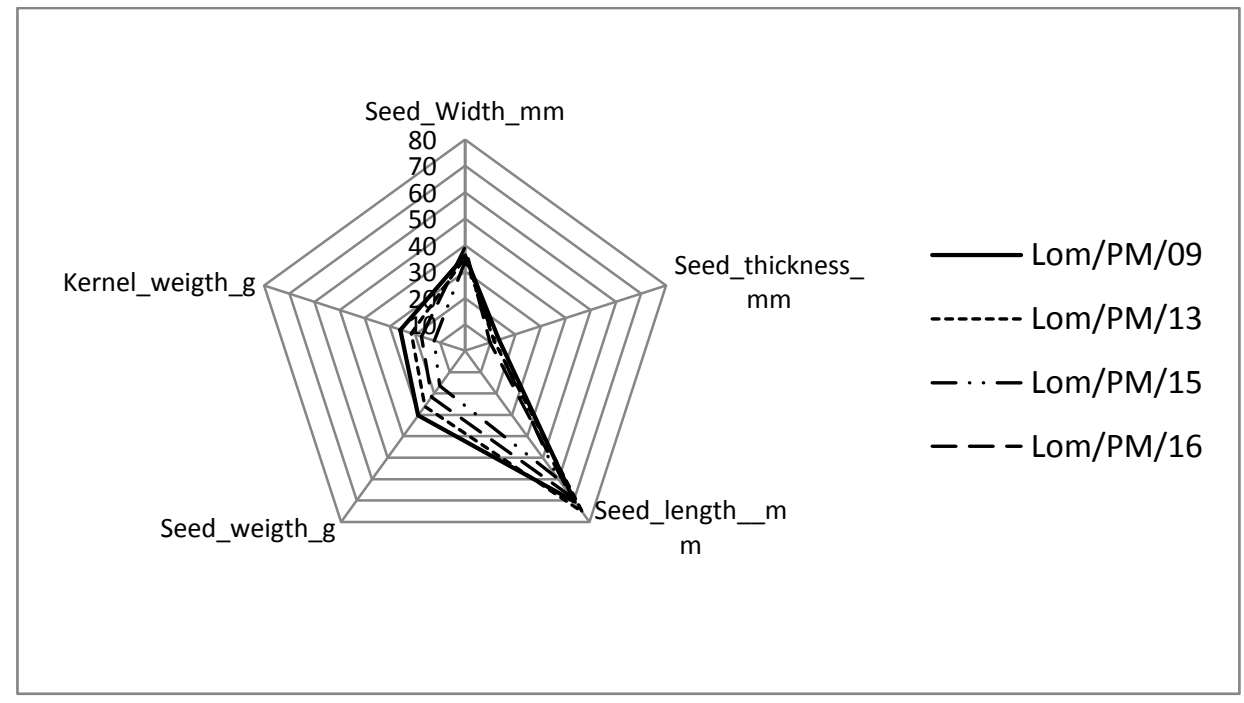

Figure 8: Spiders diagram with 5 "ideotype" characteristics of P. macrophylla 
Pearson correlations between parameters (seed width, seed length, seed thickness, seed weight and kernel weight) were significant ( $\mathrm{P}<\mathrm{o.00I}$ ). Correlations between seed and seed diameter; and between seed length and seed thickness were weak. The strongest correlation was observed between kernel weight and seed weight (Figure 9).

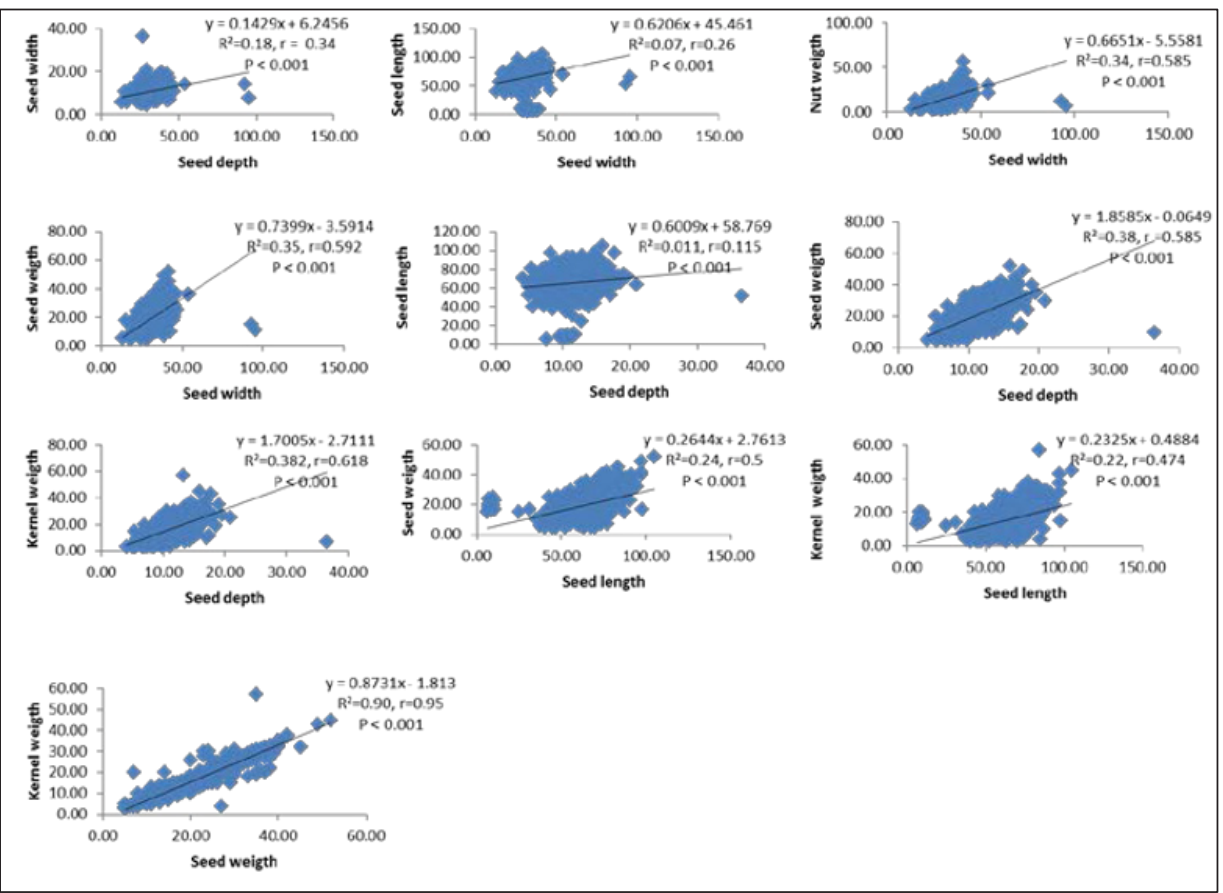

Figure g: Prediction and Correlation matrix between seeds traits $\left(R^{2}=\right.$ prediction coefficient, $r=$ Pearson's correlation coefficients, $P=$ probability)

\section{Discussion}

The lack of significant differences between populations in terms of tree $\mathrm{DBH}$, crown diameter and tree height means that the selection at population level is not efficient for these parameters. On the other hand, populations differed significantly in pod, seed and kernel parameters. This means that selection of this species based on these traits at population level is possible, assuming that all target traits are genetically controlled. However a difference in performance can also be influenced by some environmental differences between Lomie and Djoum as described below. In Lomie, the number of seeds, seed width, seed length, seed thickness, seed weight and kernel weight were greater than in Djoum. Several authors have described the variation in fruit/seed traits among populations of tree species such as Adansonia digitata (Assogbadjo et al., 2005); Allanblackia floribunda (Atangana et al., 20I0) and Balanites aegyptiaca (Abasse et al., 20II). These authors largely attributed the differences to ecological factors. However, the two targeted zones in the present study are in the same agro-ecological zone i.e the bimodal humid forest. 
Consequently, differences between values for traits in this study can be not attributed to ecological factors.

Other factors that affect tree performance in natural stands are chemical and physical soil properties or irradiance that influences photosynthetic activity and thus phenotypic aspects. In Lomie, most trees sampled were found to occur in home gardens and fallow fields, whereas in Djoum most sampled trees were from the forest. Generally, home gardens and fallows systems are richer in light and nutrients, while in the forest there is less light and lower soil fertility (Alavalapati and Mercer, 2004). The differences observed could thus be attributed to soil properties and irradiance. Genetic differences may also exist between the populations, but we do not have any data on the genetic variation of trees in this study. Studies of soil properties and irradiance (or the carbohydrate richness of this species in its natural stand) as well as the genetic variation within the different populations could help to better explain the differences observed.

At the level of tree-to-tree variation, pod, seed and kernel traits varied significantly among sampled P. macrophylla trees. As suggested by Leakey et al. (2002) on Dacryodes edulis, the observed intraspecific variation is an opportunity to select elite trees for cultivar development. Therefore, the characterization of P. macrophylla to select so-called plus trees for domestication purpose is crucial (Erickson et al., 2006).

Based on recommendations by Leakey and Page (2006), tree number LOM/PM/o9 could be used for cultivar/new variety development of P. macrophylla, because it had the highest kernel weight and the highest number of seeds per pod (with the assumption that the number of seeds per pod can be correlated with yield). As far as the oil content of kernels for industrial purposes is concerned, a wider characterization has to be carried out to study other kernel traits such as quantity of oil and its biochemical composition. For example, Atangana et al. (2010) recommended the creation of a new ideotype with not only a high weight, but also a high concentration of nutritive values or active ingredients (mineral, vitamin, protein, lipid, energy, and carbohydrate) during A. floribunda oleic and stearic acid content characterization. Assogbadjo et al. (2005) did similar work on biochemical variation of Adansonia digitata.

Our study found a strong positive correlation between seed and kernel parameters. As described by Leakey et al. (2000) on Irvingia gabonensis, future characterization could be restricted to measuring seed weight rather than kernel weight, thereby saving time and money. In contrast to species valued for both fruit and kernel (like I. gabonensis), an ideotype tree will be based on kernel traits only, because the kernel is the most commercialised part of this species (Ehiagbonare and Onyibe, 2008). However, other traits should not be neglected since they also have considerable importance. For example, seed size is important because the pericarp is used for medicine (Koné et al., 2008), whereas tree size could be exploited for carbon sequestration- related purposes.

This is the first study of phenotypic variation in tree growth and seed traits among populations of P. macrophylla trees. This study provides baseline information for the domestication of the species. This study has highlighted variation between two populations, identified tree-to-tree variation and relationships between some key traits and defined 
some ideotypes. However, there is further need to study genetic variation parameters in order to understand the genetic contribution to the observed phenotypic variation. In addition, future studies might widen the scope of the present study to include other populations (country and regional level) in order to gain a global view of P. macrophylla.

\section{Acknowledgment}

This research was funded by the International Fund for Agricultural Development (IFAD) and Belgian Development Cooperation (DGDC).

\section{References}

Ambassa-Kiki, R. (2000). Caractérisation biophysique succincte des différentes zones agro-écologiques du Cameroun. IRAD - Yaoundé. p. 6.

Abasse, T., Weber, J.W., Katkore, B., Boureima, M., Larwanou, M., Kalinganire, A. (20II). Morphological variation in Balanites aegyptiaca fruits and seeds within and among parkland agroforests in eastern Niger. Agroforest Syst 81: 57-66.

Alavalapati, J.R.R., Mercer, E.D. (2004). Valuing Agroforestry Systems : Methods and applications. Kluwer Academic Publisher. Dordrecht, Boston, London. p. 3 I4.

Assogbadjo, A.E., Sinsin, B., Codjia, J.T.C., Van Damme, P. (2005). Ecological diversity and pulp, seed and kernel production of the baobab (Adansonia digitata) in Benin. Belg. J. Bot. I38(I): 47-56.

Atangana, A.R. (2010). Phenotypic diversity in fruit and seed traits and neutral genetic diversity in Allanblackia floribunda. PhD Thesis. University of Laval. p. I02.

Atangana, A.R. Tchoundjeu, Z., Fondoun, J.-M., Asaah, E.K., Ndoumbe, M., Leakey, R.R.. (200I). Domestication of Irvingia gabonensis: $\mathrm{I}$. Phenotypic variation in fruit traits in 52 trees from two populations in the humid lowlands of Cameroon. Agroforestry Systems 53: 55-64.

Bodian, A., Ndoye-Ndi, K., Sané, D., Diaga, D., Diedhiou, (2010). Analysis of genetic variability of six date palm (Phoenix dactilifera) cultivars from Mauritania using microsatellite markers. DADOBAT symposium, Benin October 2010. p. 54 .

Donald, C.M. (1968). The breeding of crop ideotypes. Euphytica. 17: 385-403.

Ehiagbonare, J.E. and Onyibe, H.I. (2008). Regeneration studies on Pentaclethra macrophylla Beth. Scientific Research and Essay, Vol. 3 (II): 53I-536.

Eriksson, G., Ekberg, I., Clapham, D. (2006). An Introduction to Forest Genetics. Second edition. ISBN. p. 186.

Eyog Matig, O., Ndoye, O., Kengue, J., Awono, A. (2006). Les fruitiers forestiers comestibles du Cameroun. IPGRI. p. 220.

Gill, L. S. (1992). Ethnomedical uses of plants in Nigeria. University of Benin, Benin City, Edo State, Nigeria. pp. 184-185.

Koné, I., Lambert, J.E., Refisch, J., Bakayoko, A. (2008). Primate seed dispersal and its potential role in maintaining useful tree species in the Taï region, Côte-d'Ivoire: implications for the conservation of forest fragments. Tropical Conservation Science. I(3): 293-306.

Ladipo, D.O., Boland, D. J. (1995). Pentaclethra macrophylla: a multipurpose tree from Africa with potential for agro forestry in the tropics. NFT Highlights, NFTA 95-05, September 1995. Winlock Int., Morrilton AR, United States, p. 4.

Leakey, R.R.B. (200I). Win-Win land use strategies for Africa: 2. Capturing economic and environment benefits with multistrata agroforests. International Forestry Review 3: 33I-340. 
Atangana, A.R., Kengni, E., Wahuriu, A.N., Usoro, C., Anegbeh, P.,O., Tchoundjeu, Z. (2002). Domestication of Dacryodes edulis in West and Central Africa: characterization of genetic variation. Forests, Trees and Livelihoods I2: 57-7I.

Fondoun, J-M, Atangana, A, Tchoundjeu, Z (2000) Quantitative descriptors of variation in the fruits and seeds of Irvingia gabonensis. Agroforestry Systems 50: 47-58.

_ Page, T (2006). The 'ideotype concept' and its application to the selection of cultivars of trees providing agroforestry tree products. Forests, Trees and Livelihoods, I6:I: 5-16

Mac Dicken, K., Wolf, G., Briscoe, C. (I99I). Standard Research Methods for Multiplepurpose Trees and Shrubs (Vol. Manual No. 5). Winrock International Institute for Agricultural Development.

Mandeng, N.M.O. (2009). Evaluation des potentialités de domestication de l'ebaye (Pentaclethra macrophylla Benth.) Par les pygmées baka de l'arrondissement de Djoum, région du Sud Cameroun. BSc dissertation, University of Dschang - Cameroon, p. 82.

Mbong, E.S.E. (2009). Analyse socioéconomique et prioritisation des espèces exotiques et locales à haute valeur socioéconomique et culturelle pour les Baka du grand Djoum. Rapport d'études. Partenariat ICRAF-Projet AGEFO.ICRAF. p. 45.

Ngo Mpeck, M.L., Asaah, E., Tchoundjeu, Z., Atangana, A.R. (2003). Strategies for the domestication of Ricinodendron heudelotii: evaluation of variability in natural populations from Cameroon: Food Agriculture \& Environment. I (3/4): 257-262.

Ngueko, R. (2008). Evaluation de la première phase du système d'information des marchés des PFNL. Projet GCP/RAF/408/EC "Mobilisation et renforcement des capacités des petites et moyennes entreprises impliquées dans les filières des produits forestiers non ligneux en Afrique Centrale ». FAO CIFOR SNV ICRAF COMIFAC. p. I6.

Oboh, G. (2007). Pentaclethra macrophylla. [Internet] Record from PROTA4U. van der Vossen, H.A.M. \& Mkamilo, G.S. (Editors). PROTA (Plant Resources of Tropical Africa / Ressources végétales de l'Afrique tropicale), Wageningen, Netherlands. http://www.prota4u.org/search.asp. Accessed 5 January 2013.

Simons, A.J., Leakey, R.R.B. (2004). Tree domestication in tropical agroforestry. Agroforestry systems, 6I: I67-I8I.

Tsobeng, A., Asaah, E., Makueti, J., Tchoundjeu, Z., Van Damme, P. (2013). Propagation of Pentaclethra macrophylla Benth (Fabaceae) through seed and rooting of leafy stem cuttings. International Journal of Agronomy and Agricultural Research, Vol. 3, No. I2, p. I0-20, 201.

Vivien J., Faure, J.J. (1996). Fruitier Sauvage d'Afrique: espèces du Cameroun. CTA et Ministère Français de la Coopération. p. $4 \mathrm{I} 6$.

Waruhui, A.N., Kengue, J., Atangana, A.,R., Tchoundjeu, Z., Leakey, R. B. (2004). Domestication of Dacryodes edulis. 2. Phenotypic variation of fruit traits in 200 trees from four populations in the humid lowlands of Cameroon. Foods, Agricultural \& Environment, 2 (I): 340-346.

World Agroforestry Centre (2009). Promoting Rural Innovation through Participatory Tree Domestication (IFAD III project). First Implementation Progress Report, January - July 2009. I7 p. 